\title{
Literatura e Pós-Modernismo
}

\author{
Post-Modernismo no romance \\ português contemporâneo. Fios \\ de Ariadne. Máscaras de Proteu.
}

ARNAUT, Ana Paula.

Coimbra: Almedina, 2002. 387p.

Num momento em que os autores de estudos teóricos na área das Humanidades têm cada vez mais dificuldades em encontrar uma editora conceituada em Portugal, a publicação da dissertação de doutoramento de Ana Paula Arnaut - pela Editora Almedina, sediada em Coimbra - apresenta-se como um feito quer de excelência acadêmica, quer de perspicácia editorial. O texto de Ana Paula Arnaut é uma análise coerente, pensada, minuciosa e teoricamente coesa do Pós-Modernismo na literatura portuguesa. Tem também o mérito de se constituir no primeiro estudo alargado sobre esse período literário visto à luz de teorias do PósModernismo norte-americano. Ao longo do estudo, Ana Paula Arnaut entretece o seu sólido conhecimento teórico com aturadas leituras de textos cuidadosamente selecionados, de forma a facultar uma nova aproximação ao PósModernismo português. Uma aproximação que suporta a tese de que o Pós-Modernismo em Portugal deve, de fato, ser levado a sério, contrariando assim a posição de certos críticos portugueses que, muito prontamente, têm negado a importância desse período literário.

Afastando-se, propositadamente, de textos que têm sido considerados parte do cânone acadêmico, o corpus escolhido engloba um conjunto de romances que, segundo a autora, representam e ilustram os mais significativos códigos do Pós-Modernismo. O corpus selecionado abrange as últimas quatro décadas do século XX e compõe-se de oito romances da autoria de quatro autores. A saber: O Delfim (1968) e Balada da Praia dos Cães (1982), de José Cardoso Pires; Manual de pintura e caligrafia (1977) e História do cerco de Lisboa (1989), de José Saramago; Amadeo (1984) e As batalhas do Caia (1995), de Mário Cláudio; e Era bom que trocássemos umas idéias sobre o assunto (1995) e A paixão do Conde de Fróis (1986), de Mário de Carvalho. O critério que presidiu a seleção desse corpus é justificado de forma convincente na Introdução da tese, sendo posteriormente desenvolvido nos capítulos subseqüentes. Dos romances que fornecem a base de análise textual desse estudo crítico, a escolha de O Delfim como ponto de partida para o início do Pós-Modernismo português - fato que a autora reitera e eficazmente demonstra no Capítulo I - é, talvez, o aspecto mais inovador desse trabalho, pois se traduz num posicionamento que, de modo claro e audaz, contraria outras posições críticas que optam por considerar o ponto de ruptura literária numa data anterior. O estudo de Ana Paula Arnaut encara o Pós-Modernismo à luz de coordenadas estéticas e ideológicas anteriores, ao mesmo tempo que visa a redefinir e analisar as suas principais características.

Post-Modernismo no romance português contemporâneo compõe-se de uma introdução genérica, cinco capítulos e uma conclusão seguida de uma bibliografia e de um índice de autores, ambos de fácil consulta. A Introdução faculta uma panorâmica dos capítulos seguintes e delineia os diferentes problemas e questões que constituem o cerne do estudo. O objetivo da análise é articulado de forma clara à medida que a autora justifica a escolha dos romances e as aproximações teóricas aos assuntos em discussão. No Capítulo I a autora faculta uma valiosa introdução teórica ao Pós-Modernismo, aborda os debates em curso entre diversos teóricos pós-modernistas e discute os problemas inerentes a essa área de trabalho. As bem fundamentadas 50 páginas desse capítulo, escudadas em abundantes referências bibliográficas, constitui, em todos os sentidos, um excelente resumo e análise de alguns dos mais essenciais estudos do Pós-Modernismo. Reforçado por notas de rodapé detalhadas e informação bibliográfica precisa, esse capítulo, apesar de denso em alguns momentos, constitui um dos aspectos mais valiosos desse estudo, pois a autora vai além de um comentário meramente descritivo sobre (predominantemente) teóricos norteamericanos, enveredando por uma análise minuciosa de aspectos relacionados com o PósModernismo, desse modo fornecendo ao leitor, sem dúvida, os instrumentos necessários à compreensão dos problemas inerentes a essa área literária. O Capítulo II desloca a discussão 
da academia norte-americana para a cena literária portuguesa, à medida que a autora discute a transição do Modernismo e dos conceitos ideológicos subjacentes ao $\mathrm{Neo}$ Realismo para o Pós-Modernismo, tal como se encontra ilustrado pelo fundador romance de José Cardoso Pires, O Delfim. A análise de Ana Paula Arnaut ilustra essa "ruptura" literária como a invenção de uma nova tradição estética que inaugura uma original cena literária que, todavia, respiga coordenadas estéticas e ideológicas de períodos literários anteriores. Esse ponto delineia o trabalho de base para o Capítulo III. Neste, a ênfase desloca-se para Manual de pintura e caligrafia, de José Saramago, ao qual se segue a discussão de Amadeo, de Mário Cláudio, e de Balada da Praia dos Cães, de José Cardoso Pires, como textos ilustrativos da problemática confluência de gêneros literários num mesmo romance, um aspecto que a autora considera como uma das características fundamentais do Pós-Modernismo. O Capítulo IV aborda a problemática da referencialidade vs nãoreferencialidade. Esta é vista como um desafio, e também como um afastamento, em relação a tradicionais modos de representação. A autora reporta-se novamente a Manual de pintura e caligrafia, de José Saramago, e aborda, ainda, As batalhas do Caia, de Mário Cláudio, e Era bom que trocássemos..., de Mário de Carvalho, discutindo o modo como esses romances ilustram essa crise de representação. O quinto e último capítulo analisa a reescrita pós-modernista da História levada a cabo por alguns romances históricos, nomeadamente História do cerco de Lisboa, de José Saramago, e A paixão do Conde de Fróis, de Mário de Carvalho. A conclusão da dissertação apresenta uma síntese dos mais importantes aspectos abordados ao longo dos diversos capítulos, reiterando as principais teses apontadas, em particular a importância de $O$
Delfim para a compreensão do Pós-Modernismo português.

Como já sublinhamos, esse livro foi inicialmente apresentado como tese de doutoramento da autora, sendo, por conseguinte, claramente direcionado para um público acadêmico. A abundância de referências bibliográficas e de longas notas de rodapé que complementam o corpo do texto fornecem um amplo material de leitura suplementar. No entanto, caso assim se entenda, o texto pode ser consultado sem recurso a essa informação. Aduza-se ao exposto que da leitura do livro ressalta uma grande preocupação com a clareza da exposição: os capítulos são equilibrados, claramente definidos e divididos em subcapítulos que facilitam a sua compreensão; a ilustração de conceitos-chave é, com freqüência, reforçada com diversos exemplos e com citações teóricas cuidadosamente escolhidas; os jargões retóricos são evitados, sendo as idéias delineadas a partir de uma linguagem clara e fluida. Deve ainda ser louvada a atenção da autora ao detalhe, visível quer na bibliografia específica, quer na natureza pormenorizada da investigação teórica. Esse estudo torna-se, pois, uma valiosa aquisição para a biblioteca de qualquer estudioso de literatura portuguesa contemporânea e, tendo em conta os sólidos fundamentos teóricos em que se baseia, torna-se também útil aos estudos comparados do Pós-Modernismo. Post-Modernismo no romance português contemporâneo traduz a dedicação de Ana Paula Arnaut a uma investigação séria ao longo da última década, representando anos de problematização e de espírito críticos. Desse modo, o livro em apreço oferece-se como fundamental ponto de partida para posteriores leituras do romance português contemporâneo.

Kathryn M. Sanchez University of Wisconsin, Madison 